\title{
Perspectives of land evaluation of floodplains under conditions of aridification based on the assessment of ecosystem services
}

\author{
Dénes LÓCZY ${ }^{1}$, Gergely TÓTH ${ }^{2}$, TAmás HERMANN², Marietta REZSEK ${ }^{3}$, \\ GÁbor NAGY ${ }^{1}$, József DEZSŐ ${ }^{1}$, Ali SA LEM ${ }^{3,4}$, Péter GYENIZSE ${ }^{1}$, \\ Anne GOBIN ${ }^{5}$ and Andrea VACCA ${ }^{6}$
}

\begin{abstract}
Global climate change has discernible impacts on the quality of the landscapes of Hungary. Only a dynamic and spatially differentiated land evaluation methodology can properly reflect these changes. The provision level, rate of transformation and spatial distribution of ecosystem services (ESs) are fundamental properties of landscapes and have to be integral parts of an up-to-date land evaluation. For agricultural land capability assessment soil fertility is a major supporting ES, directly associated with climate change through greenhouse gas emissions and carbon sequestration as regulationg services. Since for Hungary aridification is the most severe consequence of climate change, water-related ESs, such as water retention and storage on and below the surface as well as control of floods, water pollution and soil erosion, are of increasing importance. The productivity of agricultural crops is enhanced by more atmospheric $\mathrm{CO}_{2}$ but restricted by higher drought susceptibility. The value of floodplain landscapes, i.e. their agroecological, nature conservation, tourism (aesthetic) and other potentials, however, will be increasingly controlled by their water supply, which is characterized by hydrometeorological parameters. Case studies are presented for the estimation of the value of two water-related regulating ESs (water retention and groundwater recharge capacities) in the floodplains of the Kapos and Drava rivers, Southwest Hungary. It is predictable that in the future land evaluation techniques based on the FAO framework will be more dynamic and integrated with the monetary valuation of ESs. The latter task, however, still involves numerous methodological problems to solve.
\end{abstract}

Keywords: land evaluation, climate change, aridification, ecosystem services, floodwater retention, groundwater recharge, flood reservoirs, floodplains

Received March 2020; Accepted August 2020.

\section{Introduction}

Conventional land evaluation approaches are either land capability or land suitability surveys. Land capability assessment is meant to measure the overall agroecological potential of a region to produce common cultivated crops and pasture plants (or forestry) without deterioration over a long period of time (BeEK, K.J. and Bennema, J. 1972; FAO 1976; Davidson, D.A. 1992). 'Land with the highest capability is expected to be versatile and

\footnotetext{
${ }^{1}$ Institute of Geography and Earth Sciences, University of Pécs, H-7624 Pécs, Ifjúság útja 6. Hungary. E-mails: loczyd@gamma.ttk.pte.hu, gnagy@gamma.ttk.pte.hu, dejozsi@gamma.ttk.pte.hu, gyenizse@gamma.ttk.pte.hu

${ }^{2}$ Georgikon Faculty, University of Pannonia, H-8360 Keszthely, Deák Ferenc u. 16. Hungary.

E-mails: toth.gergely@georgikon.hu, hermann.tamas@georgikon.hu

${ }^{3}$ Doctoral School of Earth Sciences, University of Pécs, H-7624 Pécs, Ifjúság útja 6. Hungary.

E-mails: rezsekma@gamma.ttk.pte.hu, alisalem@gamma.ttk.pte.hu

${ }^{4}$ Civil Engineering Department, Faculty of Engineering, Minia University, Minia 61111, Egypt.

${ }^{5}$ Flemish Institute for Technological Research (VITO), Boeretang 200, B-2400 Mol, Belgium; Department of Earth and Environmental Sciences, Faculty of BioScience Engineering, University of Leuven, Celestijnenlaan 200E, 3001 Heverlee, Belgium. E-mail: anne.gobin@vito.be

${ }^{6}$ Department of Chemical and Geological Sciences, University of Cagliari, Cittadella Universitaria (Axis D), I-09042 Monserrato, Italy. E-mail: avacca@unica.it
} 
allow intensive use for a reasonably large range of enterprises' (McRAE, S.G. and BuRNHAM, C.P. 1981, p. 67). Developed into integral land evaluation (SмIт, B. et al. 1984), land capability surveys help identify the processes of land degradation (KERTÉsz, Á. and Ǩ̌EČEK, J. 2019) and contribute to the foundation of regional development policies. Land suitability assessment is contrived to measure the adaptability of a given area for a specific kind of land use at a given date (FAO 1976).

In Hungary the more than 140-year old 'Goldkrone' system of land evaluation of the Austro-Hungarian Monarchy is still in use although it will be hopefully soon replaced by the D-e-meter system under development (Dér, F. et al. 2007; То́тн, G. 2009). The D-e-meter is a scientifically based system, which equally considers topography, the water and nutrient availability and complex properties of soils of high spatial but low temporal variability (PÁszTor, L. et al. 2013) as well as the type of cultivation according to their true significance in land quality. On the scale from 1 to 100 , floodplain soils are placed between 30-70 scores in the variety for intensive land use and 20-50 in the extensive variety. In addition, climate (and thus environmental dynamics) is also considered: for the 75 agrometeorological subdivisions of the country by the yields of agricultural crops three kinds of years are distinguished:

- optimal years (when maximum production is achieved),

- 'expected' years (when production is at average level), and

- poor years (when yields are considerable lower).

The system is designed to allow regular updates based on time series information, thus able to incorporate the effect of climate change and the change in agrotechnology as well. Apart from the scientifically sound conceptualisation of soil productivity model, including the effect of climate, soil and management factors (То́тн, G. 2009) other building blocks, such as time series yield and biomass data, validation datasets (case studies, long term field experimental data) and detailed soil maps for the country (PÁsztor, L. et al. 2017; То́тн, G. et al. 2018) enable to develop a productivity map for all agricultural land of the country. However, the evaluation system is only capable of predicting future changes in productivity to a limited extent.

Since the seminal (and much criticized) paper by Costanza, R. et al. (1997) on the value of global natural capital and the Millenium Ecosystem Assessment (MEA 2005), ecosystem services (ESs), with emphasis on regulating services, have become a central topic of environmental research. As this concept places the welfare of human society in the focus, this is a novel approach to the assessment of environmental quality. In the most simple definition of the often debated term, ESs are a set of ecosystem functions which are useful to humans (Kremen, C. 2005). According to Costanza, R. and Folke, C. (1997) ESs are 'the benefits human populations derive, directly or indirectly, from ecosystem functions'. Fischer, B. et al. (2009) claim that the so-called intermediate services interact to produce final services, which include floodwater retention and freshwater provision. Other pioneers of the ES approach (Ротsснin-Young, M. et al. 2017) question the applicability of the concept of intermediate services. The multiple functions of the landscape (i.e. ESs) are jointly evaluated (SchindLER, S. et al. 2013, 2014), particularly often for landscapes (like floodplains) where water is the decisive component (e.g. Martin-Ortega, J. et al. 2015). However, value judgements on individual services are made difficult by the trade-offs between them (SANON, S. et al. 2012).

The assessment of anticipated changes in the level of provision of ESs is increasingly incorporated in planning (Albert, C. et al. 2014, 2016), found essential for achieving landscape sustainability (Wu, J. 2013) and assumed to serve as a measure of effectiveness for rehabilitation works (AleXANDER, S. et al. 2016). Concerning ESs, the elaboration of precise and objective indicators is the most important task in the opinion of many authors (Haines-Young, R. et al. 2012). Appropriate methods have to be developed 
to translate the provision of ESs to a set of parameters. This task can only be accomplished in close cooperation between experts in (landscape) ecology and environmental economics (Thurston, H.W. et al. 2009). The valuation procedure, however, should be as simple as possible (Simpson, R.D. 2017).

The EU Biodiversity Strategy to 2020 foresees that Member States map and assess the state of ecosystems and their services on their territories (Zulian, G. et al. 2013; ERHARD, M. et al. 2017; MAEs, J. et al. 2018; Rendon, P. et al. 2019). The starting point was the list of ESs compiled as CICES 4.3 (Common International Classification of Ecosystem Services - Haines-Young, R. and Potschin, M. 2018). In Hungary the National Mapping and Assessment of Ecosystem Services (NÖSZTÉP) was launched in 2017 (TANÁcs, E. et al. 2019). In the first step the research budget only allowed the identification of indicators for a limited number of ESs.

Numerous techniques have been proposed for the assessment and valuation of water-related ESs (GrizzetTI, B. et al. 2016; TAlвот, C.J. et al. 2018; Hornung, L.K. et al. 2019). Water availability is among the temporally most variable land qualities, which is of crucial significance for agriculture (LóczY, D. 2000; Falkenmark, M. 2013). Although often evaluated globally (e.g. Gerten, D. et al. 2011), it is basically a regional property which cannot simply be described by pointlike data (e.g. from soil survey), but the indicators of water availability have to reflect the landscape context, cascading and neighbourhood effects ( $\mathrm{X}_{\mathrm{U}}, \mathrm{H}$. and Wu, M. 2017; DuARte, G. et al. 2018). The water footprint is a concept employed by ecologists in the assessment of sustainability and efficiency of water use in a catchment (LovARELLI, D. et al. 2016; Roux, B. et al. 2017).

Naturally, flood mitigation is a highprofile ES (BARTH, N.-C. and DöLL, P. 2016; Opperman, J.J. et al. 2017). Permeable floodplain deposits allow floodwater storage and the ability to mitigate floods (Lü, S.B. et al. 2012). The substitute cost approach (comparison with alternatives such as man-made reservoirs) is readily applicable to estimate the value of the flood mitigation service provided by wetlands. In the priority list set up on the basis of willingness to pay, flood control is also the most valuable ES of wetlands (Brower, R. et al. 1999). In an American case study (Mud Lake, South Dakota) the flood control service of wetlands was valued (based on monetary damages prevented) much higher (at ca. USD 440 per acre, i.e. ca. EUR 1016 ha $^{-1} \mathrm{y}^{-1}$ ) than water supply (public utility revenues, at USD 94 per acre, i.e. ca. EUR 217 ha $^{-1} \mathrm{y}^{-1}$ ) and other services (RoBERTS, L.A. and LeITCH, J.A. 1997). In a more recent and more detailed investigation (CUI, L.J. et al. 2016) climate regulation makes up 62.0 per cent of the gross value of ultimate ESs provided by the Zhalong wetland (along the Wuyuer River, Heilongjiang province, China), while the value of flood regulation amounts to 33.3 per cent. It was found that German riparian forests avoid damage from a 10-year flood in the value of EUR 4,300 ha- $\mathrm{y}^{-1}$ (BARTH, N.-C. and DöLL, P. 2016).

The flood control service is closely related to another important service, groundwater replenishment, since with the storage of floodwater in soils and reservoirs promotes its deep percolation (Foster, T. et al. 2017). Localized recharge can be more efficient than diffuse recharge (SCANLON, B.R. et al. 2002). Key sites of surface water/groundwater interactions (Griebler, C. and Avramov, M. 2015; Salem, A. et al. 2020) are Groundwater Dependent Ecosystems (GDEs) like swamps and other wetlands (EAmus, D. et al. 2016). The undrained surfaces of the Hungarian Drava Plain mapped within the framework of the Old Drava landscape rehabilitation programme (Trinity Enviro 2018) can be regarded as GDEs (Figure 1).

Actual recharge demonstrably reaches the water table, while potential recharge feeds the moisture content of the unsaturated zone but it could potentially also contribute to groundwater in the aquifer (BERGKAMP, G. and Cross, K. 2006; Walker, D. et al. 2018). Shallow (1 to $1.5 \mathrm{~m}$ deep) ponds with infiltration capacities ranging from $1 \mathrm{~m} \mathrm{~d}^{-1}$ to $5 \mathrm{~m} \mathrm{~d}^{-1}$ were found to be suitable for ar- 


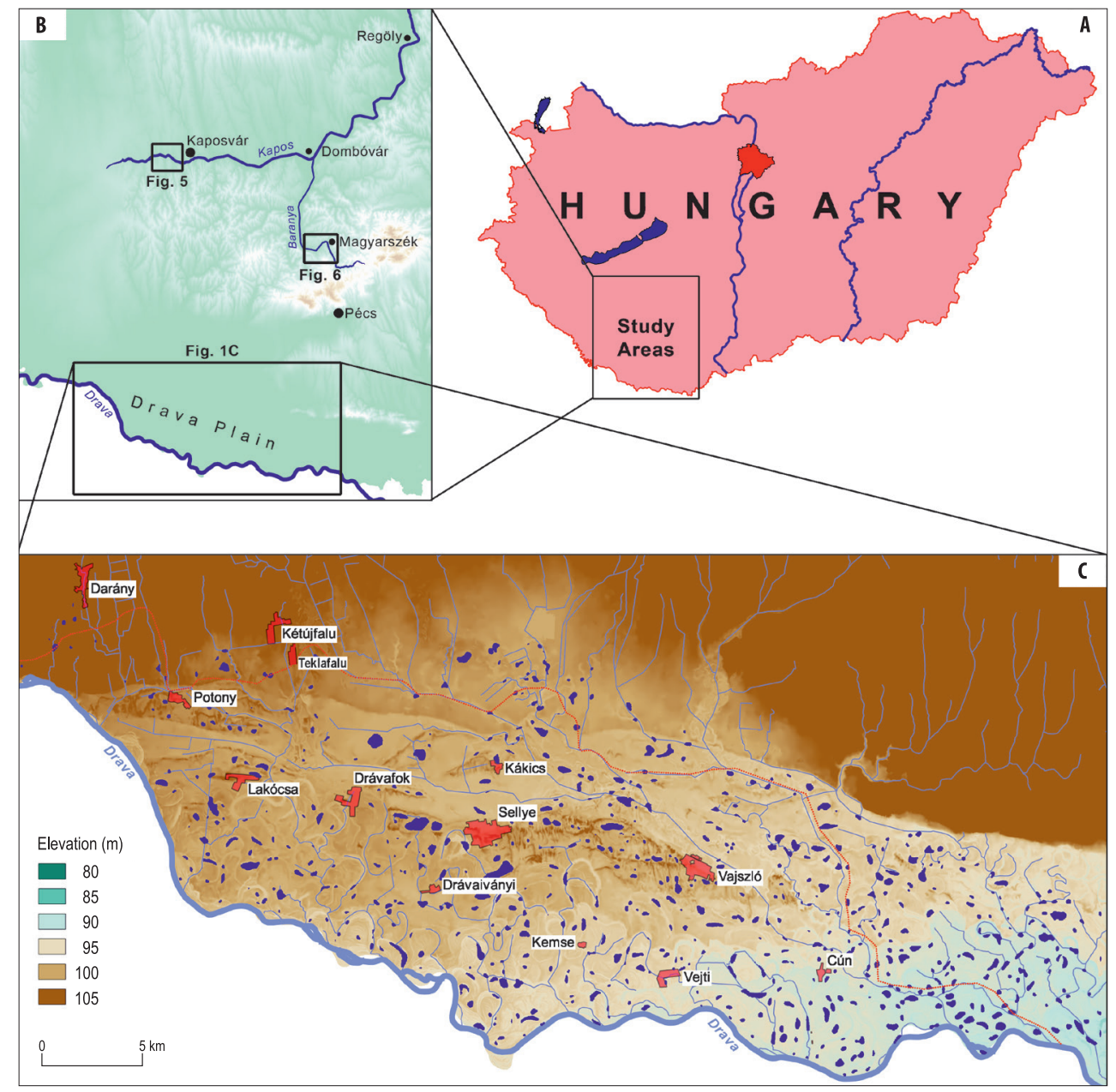

Fig. 1. The study areas in Hungary (1A) and in Southern Transdanubia (1B). 1C = Closed depressions (undrained surfaces), key areas of groundwater recharge, in the landscape rehabilitation area of the Hungarian Drava Plain (drawn by Gyenizse, P. after Trinity Enviro 2018). Pink dots are settlements. Numbers indicate groundwater observation wells in Table 1. Red line marks the boundary of the planning area of the Old Drava Programme.

tificial recharge (JódAR-Abellán, A. et al. 2017). A study revealed that in the semiarid New Mexico about half the floodwater retained in an experiment infiltrated and recharged groundwater (VALETT, H.M. et al. 2005). Similar examples are cited from the Mediterranean (Opperman, J.J. et al. 2010; Chang, H. and Bonnette, M.R. 2016) and semiarid African regions (ACHARYA, G. 2000; Acharya, G., and BArbier, E.B. 2000).
The economic value of the groundwater recharge service can also be estimated through the contingent valuation (or willingness to pay) method (DAmigos, D. et al. 2017) in most cases. In Hungary, however, the general public is not aware of the importance of this service, therefore, a questionnaire survey of this kind probably would not bring reliable results.

The evaluation of nutrient availability is also central in land evaluation systems. The 
problems in this field can be enlightened with the case of nitrogen. Although its actual quantification is still debated, the nitrogen cycle is one of the critical planetary boundaries (RocKströм, J. et al. 2009) as it threatens the safe operation of human society. Nitrogen loss takes place to the atmosphere (ammonia and nitrous oxide emissions) and surface and groundwater (nitrate) (vAN Grinsven, H.J.M. et al. 2015). Improper fertilizer and manure application is identified as the most important source of nitrate contamination of groundwater in agricultural regions (see e.g. DiAdin, D. et al. 2018) and can be reduced by integrating livestock and crop production. The needed planetary $\mathrm{N}$ fixation can be derived from demographic trends of the global population, the recommended dietary nitrogen consumption per capita and the efficiency of nitrogen use (DE VRIEs, W. et al. 2013).

Global climate change has an impact on the quality of ecosystems and landscapes (Figure 2). Higher atmospheric $\mathrm{CO}_{2}$ concentrations may enhance agroecological potential and improve crop performance, but increased

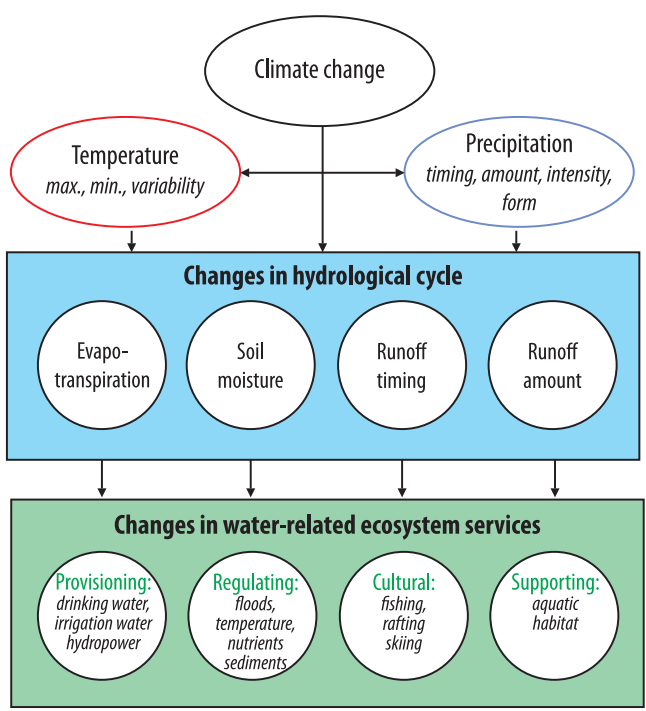

Fig. 2. Cascading effects of climate change on water related ecosystem services (ESs). Source: Modified after Chang, H. and Bonnette, M.R. 2016. temperature and water scarcity (greater susceptibility to drought) may severely restrict their impact (Gobin, A. 2010; Garofalo, P. et al. 2019; SzAвó, Sz. et al. 2019). Research shows that climate change will particularly negatively affect the yields of crops like cereals (Monaco, E. et al. 2014; Bonfante, A. et al. 2015; SAAB, M.T.A. et al. 2019), sugar beet and potatoes (Frutos CACHORRo, J. et al. 2018). Adaptation can involve modified cropping systems, for instance, sowing winter wheat instead of crops with higher water demand (Debaeke, P. et al. 2017). To this extent, crop water requirements and productivity can help make informed decisions across different regions (GobIn, A. et al. 2017). The ongoing climate change in Hungary impacts on local water resources (JANKó, F. et al. 2018; JАКАВ, G. et al. 2019), particularly drops in groundwater depth, and indirectly on soil and vegetation changes (FARKAS, J.Zs. et al. 2017; FEHÉr, Z.Zs. and RAKONCZAI, J. 2019). In the most severely affected region, on the Danube-Tisza Interfluve, a huge, more than $1,000 \mathrm{~mm}$, moisture deficit accumulated between 1971 and 1985 (Major, P. 1994). Floodplains also show groundwater deficit (for the Drava Plain see e.g. Dezső, J., Lóczy, D. et al. 2019).

The carbon sequestration capacity of soils demonstrates the impact in the opposite direction: that of soils on climate. European soils (particularly peatlands on floodplains) store huge amounts of carbon (73-79 billion tonnes) (GobIN, A. et al. 2011). Organic matter content also influences water-holding capacity, thus, soil productivity and environmental quality, and can mitigate the damage caused by droughts and floods.

Agricultural land evaluation has to account for the changeability of input data caused by changing climate (Bonfante, A. et al. 2015; Макоvníková, J. et al. 2019). The productivity of the landscapes varies with the changing circumstances and this will be even more typical in the future (FAO 2017). Although previous systems were primarily based on constant variables, there are several arguments for applying more dynamic techniques in land evaluation (BonfANTE, A. et al. 
2018). Climate change is expected to lead to short-term modifications in the yield potentials of the main economic crops in Europe although to geographically variable degrees (SupIt, I. et al. 2010; EEA 2019). While in some regions of northern Europe yield potentials tend to increase (BurKhARD, B. et al. 2009), in the Mediterranean region major changes in water availability, temperature and radiation significantly reduce potential crop yields (SCHILs, R. et al. 2018) and quality (Bonfante, A. et al. 2015, 2017). Along with natural factors, independent from climate change impacts, the vital significance of socio-economic aspects of land system development and land policy in general are often emphasized. It is claimed that social and policy factors can cause a drop of up to 56 per cent in food production (Brown, C. et al. 2019).

\section{Methodological approaches: valuation of ESs}

Environmental economists have proposed several alternatives for the valuation of ESs (Pascual, U. and Muradian, R. 2010):

- hedonic pricing: if ESs directly influence market prices;

- contingent valuation or willingness to pay: questionnaire survey of people's value perceptions;

- benefit transfer: to infer economic values from the study of similar areas under similar market conditions;

- damage cost avoidance, replacement/substitute cost: damage from lost services, providing substitute(s) for services.

Both benefit transfer and substitute cost seem to be more feasible solutions for the studied water-related ESs in Hungary than the first two which would require a higher level of environmental awareness from the public.

Acharya, G. (2000), and Acharya, G. and BARbier, E.B. (2000) investigated the costs and benefits of development projects, both direct, and indirect, which divert some water away from the floodplain for irrigation in northern Nigeria. The value of replenishing and maintaining the shallow groundwater aquifer was calculated as USD $413 \mathrm{ha}^{-1}$, the value of groundwater discharge as USD 32.5 per farmer per dry season or USD $62 \mathrm{ha}^{-1}$ and for the entire wetland: USD $13,029 \mathrm{~d}^{-1}$. Since the environmental conditions are starkly different, the transfer of these values to Hungary (see below) is not possible.

In the present paper experimentary monetary evaluations of two interrelated basic ESs are presented for two catchments in Southwest-Hungary: the Drava Plain and the Kapos Valley (see Figure 1). Both have to be regarded first approximations. As yet, the reliability of the procedure is equally made doubtful on the grounds of deficiencies in methodology and the inaccuracy of input data.

\section{Examples for the pricing of ecosystem services}

\section{Floodwater retention in floodplains}

The Water Retention Index (WRI) is a useful tool to estimate potential water retention comprehensively (VANDECASTEELE, I. et al. 2018). The WRI is calculated from the equation

$W R I=\left(w_{v} R_{v}+w_{g w} R_{g w}+w_{s} R_{s}+w_{s l} R_{s l}+w_{w b} R_{w b}\right) \cdot\left(1-\frac{R_{s s}}{100}\right),(1)$

where ws are the weights to be assigned to each parameter, and $R$ are the parameter scores given for retention in vegetation $\left(R_{v}\right)$, groundwater bodies $\left(R_{g w}\right)$, soil $\left(R_{s}\right)$, slope $\left(R_{s l}\right)$, surface water bodies $\left(R_{w b}\right)$, and for soil sealing $\left(R_{s s}\right)$.

In the study areas slope inclinations are less than 1.00 per cent and floodplain soils are only sealed in built-up areas. Therefore, the components $\mathrm{R}_{\mathrm{sl}}$ and $\mathrm{R}_{\mathrm{ss}}$ could be left out of consideration in the calculations. Moreover, increased water use of forests and grazing lands after floods cannot influence floodwater storage significantly. Thus, in floodwater retention the vegetation effect $\left(R_{v}\right)$ can also be ignored. In contrast, for drought mitigation moisture storage in the vegetation (green water) is an important factor. 
In the Drava Plain long-term precipitation is $682 \mathrm{~mm} \mathrm{y}^{-1}$, out of which groundwater recharge is $307 \mathrm{~mm}$, actual evapotranspiration (ET) is $190 \mathrm{~mm}$ and surface run-off is $185 \mathrm{~mm}$ (SAlEm, A. et al. 2019). Actual daily evapotranspiration (ET) in the growing season (April to September) only averaged $1.85 \mathrm{~mm} \mathrm{~d}^{-1}$ for the Drava Plain over the period 2000-2018 (SAlem, A. et al. 2019). For the Kapos floodplain, however, precipitation (Kaposvár) is $651 \mathrm{~mm} \mathrm{y}^{-1}$ and yearly ET ranged from 464 to $660 \mathrm{~mm}$ in the (slightly overlapping) period 1981-2003 (BАKKEN, T.H. et al. 2006). Consequently, maximum actual ET amounted to ca. $2 \mathrm{~mm} \mathrm{~d}^{-1}$ in the Kapos Valley for the growing season (Lóczy, D. 2013).

It follows from the above that floodwater retention as an ES primarily depends on the amounts of water retained in the soils/deposits and in surface water bodies. The equation that is expected to provide its value is

$$
E S_{w r}=w_{1} C_{\mathrm{s}}+w_{2} C_{w b^{\prime}}
$$

where $E S_{w r}$ is the value of the water retention service (HUF ha-1), $C_{s}$ is the value (substituted cost) of specific water storage in the soil and alluvial deposits (HUF ha ${ }^{-1}$ ), $C_{w b}$ is the value of water storage in surface water bodies (HUF ha-1), $w_{1}$ and $w_{2}$ are weights.

Using nonlinear regression for a sensitivity analysis (PAruolo, P. et al. 2013), VAndecasteele, I. et al. (2018) established a weighting to both types of water retention, where surface water bodies received exactly double optimized weight (0.24) compared to soils and deposits (0.14). We followed this weighting and arrived at an equation which points to the relative importance of these components:

$$
E S_{w r}=\left(C_{s}+2 C_{w b}\right) / 3
$$

Water retention in soils and deposits

The capacity of soils for water storage is not apparent but can be very high. It depends on the depth of the vadose zone (to the ground- water table) and soil texture or sediment macroporosity. Groundwater table depth shows strong but fairly regular seasonal dynamics (Figures 3 and 4, Table 1). This fact supplies a good argument for elaborating a dynamic evaluation of ESs that includes water retention. Extreme yearly ranges (up to $>4 \mathrm{~m}$ ) occur in some wells, but an average depth of $2.5 \mathrm{~m}$ can be accepted for the Drava Plain.

The heterogeneous sequences of floodplain deposits present a great variety of grain sizes from heavy clay and silty fine sand to gravelly coarse sand in the Drava Plain (Dezsô, J., Czigány, Sz. et al. 2019), while in the Kapos catchment few massive rocks occur and the floodplain is built up of deposits ranging from silt to coarse sand (Lóczy, D. 2013). The macroporosity of alluvial sediments above mean groundwater table depth in the Drava Plain typically ranges from 40 to 50 per cent (sands) between paleochannels and from 55 to 70 per cent in paleochannel clayey deposits (DDVÍZIG 2015; Terraexpert Kft. 2018). Geomorphological mapping in selected representative areas revealed that surfaces with deposits finer than silt make up less than 25 per cent of the total area. Therefore, 50 per cent as an average void ratio was used in the calculations.

For the calculation of below-ground water retention the following equation was used:

$$
R_{\mathrm{s}}=\left(V R \cdot D_{g w}\right) / A,
$$

where $R_{s}$ is water retention in soil and sediment, $V R$ is mean void ratio of prevailing deposit (fraction), $D_{g w}$ is depth to mean groundwater table (m), $A$ is total catchment area (ha).

The calculated mean storage is 12,600 $\mathrm{m}^{3} \mathrm{ha}^{-1}$ for the Drava Plain. In the Kapos Valley the Regöly embayment had been selected for detailed investigations. Soil profiles were analyzed for maximum (saturated) water capacity and storage capacity (water released gravitationally). The results are the following: $4,039 \mathrm{~m}^{3} \mathrm{ha}^{-1}$ for the areas with chernozem meadow soils, $1,369 \mathrm{~m}^{3} \mathrm{ha}^{-1}$ for the sand areas, $15,916 \mathrm{~m}^{3} \mathrm{ha}^{-1}$ for the meadow soil areas and $2,189 \mathrm{~m}^{3} \mathrm{ha}^{-1}$ for the wetlands (unpublished 


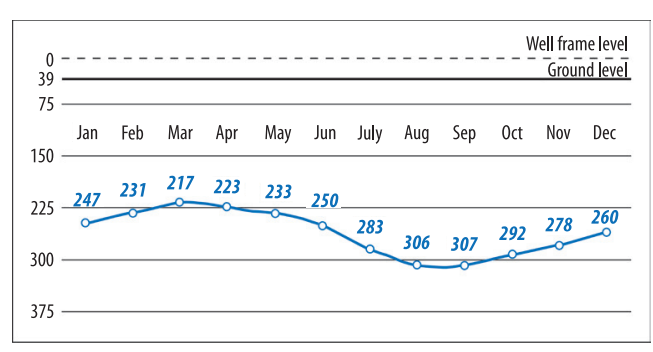

Fig. 3. Long-term monthly groundwater levels at an observation well in the Drava Plain with typical regime, Kemse, 1955-2018. Source: DDVÍZIG 2015. data by Dezső, J.). The estimated average for the Kapos Valley is $12,800 \mathrm{~m}^{3} \mathrm{ha}^{-1}$.

Consequently, specific underground floodwater storage potential is roughly equal as regards the Drava and the Kapos floodplains. As a matter of course, the dynamic potential depends on the actual depth of the groundwater table.

\section{Surface water storage}

For the catchment of the Upper Kapos $(122,000$ ha; ca. 5,500 ha of which is flood-
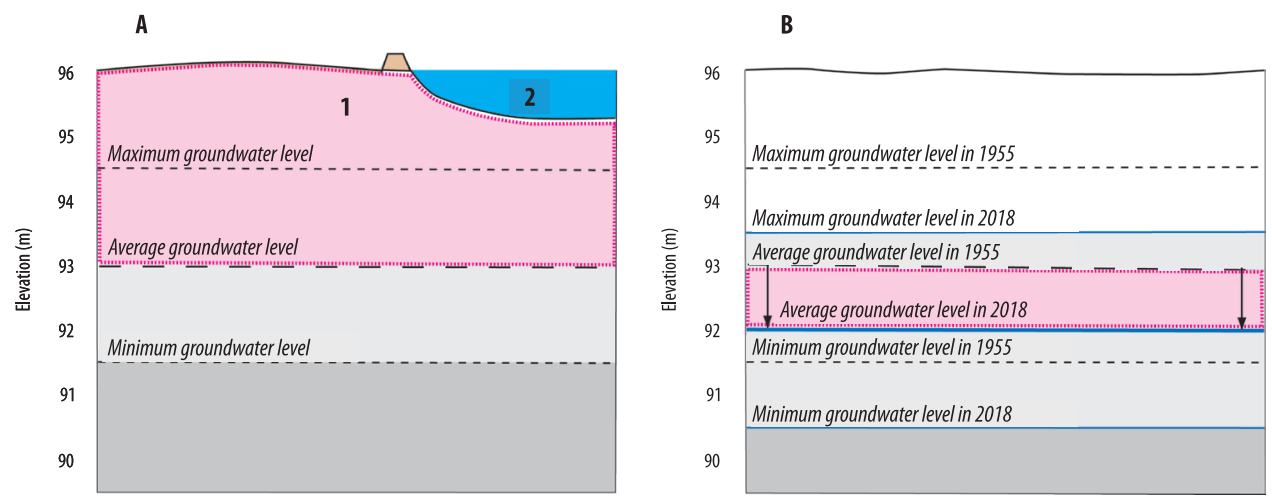

Fig. 4. Scheme of vertical zones considered for water-related ES calculations (by Lóczy, D.). A = Water retention below ground (1), on the surface (2); B = Groundwater recharge. For explanation see text.

Table 1. Groundwater levels in the observation wells of the Drava Plain*

\begin{tabular}{l|c|c|c|c|c|c}
\hline \multirow{2}{*}{ Well } & Distance from & Observation & \multicolumn{5}{|c}{ Groundwater level, $\mathrm{m}$} \\
\cline { 4 - 7 } & Drava, $\mathrm{km}$ & period & average & maximum & minimum & range \\
\hline Cún-2 & 2.7 & $2015-2017$ & 90.60 & 91.69 & 90.01 & 1.68 \\
Darány & 4.4 & $1979-2016$ & 118.64 & 120.49 & 116.37 & 4.12 \\
Drávafok & 5.3 & $1955-2016$ & 98.68 & 100.10 & 97.57 & 2.53 \\
Drávaiványi & 3.9 & $1975-2016$ & 97.52 & 99.36 & 96.11 & 3.25 \\
Kákics & 10.7 & $1975-2016$ & 97.71 & 98.92 & 99.66 & 2.26 \\
Kemse & 3.1 & $1955-2016$ & 95.28 & 96.57 & 91.87 & 4.70 \\
Kétújfalu & 9.2 & $1955-2016$ & 104.49 & 106.59 & 102.01 & 4.58 \\
Lakócsa & 3.9 & $1975-2016$ & 99.02 & 100.32 & 97.75 & 2.57 \\
Potony & 2.9 & $1955-2016$ & 100.66 & 103.17 & 99.17 & 4.00 \\
Sellye & 6.3 & $1975-2016$ & 98.09 & 99.24 & 96.83 & 2.41 \\
Vajszló & 6.5 & $1951-2016$ & 94.59 & 96.46 & 93.63 & 2.83 \\
Vejti & 1.8 & $1975-2016$ & 94.24 & 96.67 & 93.14 & 3.53 \\
\hline
\end{tabular}

*Compiled by Lóczy, D. 2019. Data source: Terraexpert Kft. 2018. For location of observation wells see Figure 1. 
plain) floodwater reservoir planning in the 1970s calculated with $3,700,000 \mathrm{~m}^{3}$ retention capacity, but the reservoirs were envisaged to be built mainly along the left-bank tributaries not on the trunk river (Szappanos, F. et al. 1976). At Dombóvár (65 river $\mathrm{km}$ ) the 10 per cent probability flood discharge could be reduced with the help of reservoir storage from $63 \mathrm{~m}^{3} \mathrm{~s}^{-1}$ to $47 \mathrm{~m}^{3} \mathrm{~s}^{-1}$. On the trunk river a flood retention reservoir of $3,500,000 \mathrm{~m}^{3}$ capacity was planned for this purpose but not built. Unfortunately, the financial calculations (HUF 41,200,000, at the present value: ca. HUF $3,500,000,000$, based on estimated purchase power parity) are completely outdated now as in the new political and economic system the investment environment is different.

For the Drava Plain, total floodwater storage capacity in the project area of the Old Drava Programme $(57,214$ ha floodplain) in the surface depressions (see Figure 1) is recently estimated at 12 million $\mathrm{m}^{3}$ (DDVÍZIG 2015). This figure can be accepted as a rough estimate of maximum water retention in surface water bodies. (Although it is doubted to what percentage such depressions can be connected to the Drava River to receive floodwater discharge.)

The application of the substitute cost method was made possible by the fact that repeated inundations of agricultural areas in many valleys of Transdanubia called for the establishment of temporary floodwater-retaining reservoirs (Szappanos, F. et al. 1976). The approximate value of natural water retention service is assumed to equal the cost of retention per unit floodplain area achieved by engineering structures (construction expenses of a dam, embankments, a feeder canal and related infrastructure). From the officially published figures (usually obtained from the South Transdanubian Water Management Directorate - DDVÍZIG) of their capacity and investment costs, the approximate expense of retaining $1 \mathrm{~m}^{3}$ of floodwater can be estimated (Table 2).

Assuming that each reservoir collects runoff from the entire catchment above the site of impoundment, the specific cost of water retention is calculated from the equation:

$$
C_{\text {swr }}=C_{\text {total }} / A_{f p^{\prime}}
$$

where $C_{s w r}$ is the cost of surface water retention (HUF), $C_{\text {total }}$ is total investment cost of the engineering structure (HUF), $A_{f p}$ is floodplain area where floodwater is stored, above the site of river impoundment (ha).

The specific cost derived from this calculation can be regarded equal to a rough estimate of the ES 'flood mitigation through surface retention' in the floodplain. Using equation (3) for the calculation of total floodwater retention potential, and taking irrigation water price at HUF $8 \mathrm{~m}^{-3}$ (KемÉNY, G. et al. 2018), the following results are achieved for the Kapos Valley: $E S_{w r}=(12,800 \cdot 8+2 \cdot 20,000 \cdot 8) / 3=\mathrm{HUF}$ 140,800 ha $^{-1}$.

The similar results for the Drava Plain: $E S_{w r}=(12,600 \cdot 8+2 \cdot 16,000 \cdot 8) / 3=\mathrm{HUF}$ $118,900 \mathrm{ha}^{-1}$.

The ES values for the two floodplains of similar character are fairly close to each other.

\section{Groundwater recharge in the Drava floodplain}

The pricing of groundwater replenishment service cannot be solved by the substitution cost approach since no technology is known that could supply sufficient amounts of surface water to fill up groundwater reserves.

The aquifer under the Hungarian Drava Plain can be regarded a conditionally independent unit - although it is linked to the right-bank unit in Croatia. The focal areas of groundwater recharge are the closed depression represented in Figure 1. Table 3 summarizes the (sparse) data available to describe the groundwater situation in the Hungarian Drava Plain.

Extracted unconfined groundwater is primarily used for irrigation $(92 \%$ in arable farming, $7 \%$ in horticulture, $1 \%$ in other branches) since its quality is not suitable for drinking water (because of nitrate contamination). Therefore, the price of irrigation water (as a main component of the operation cost of irrigation systems) can be used in the calculation of the ES values. 

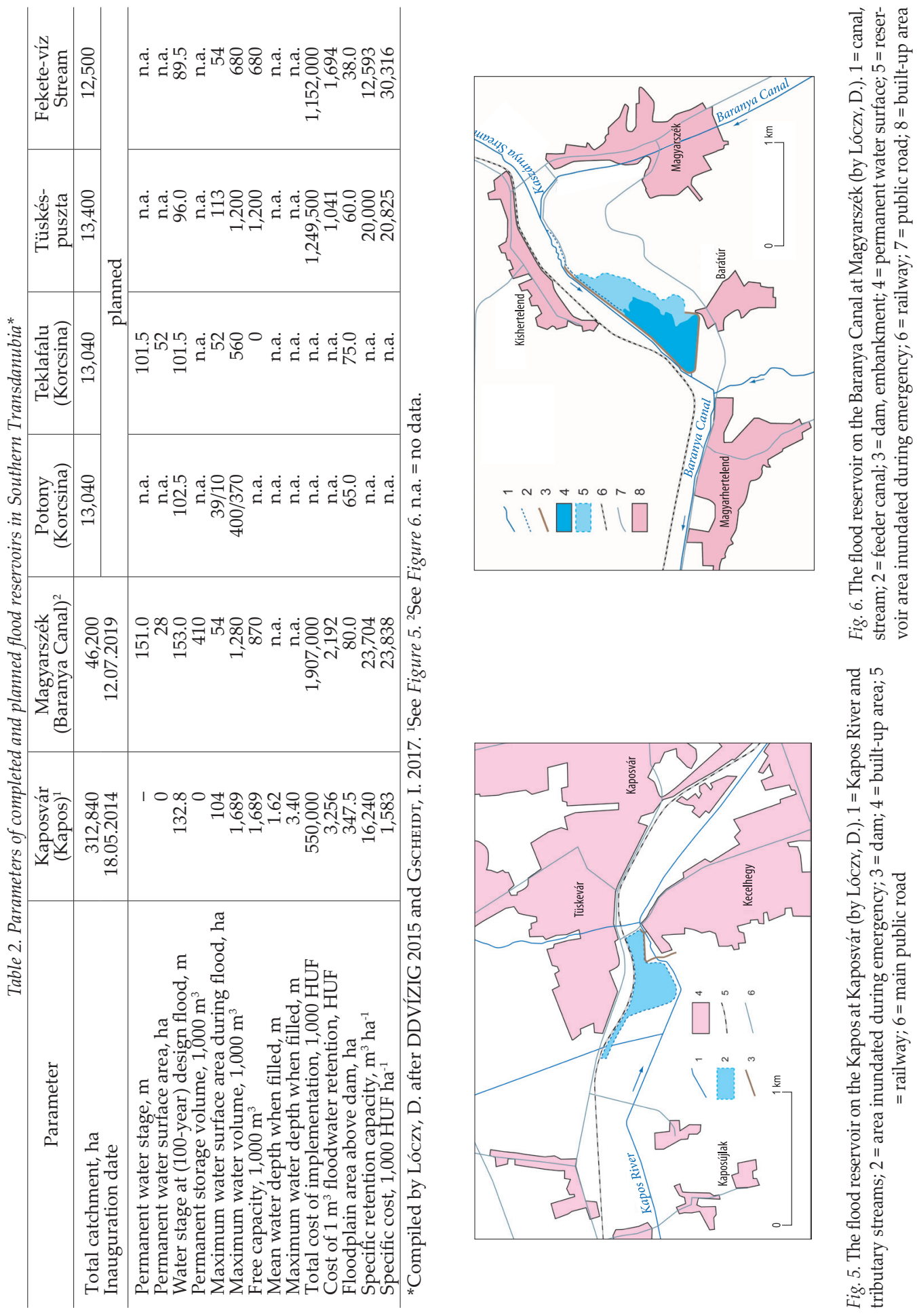
Table 3. Groundwater reserves of the Hungarian Drava Plain*, their exploitation** and costs of water utilization***

\begin{tabular}{l|c|c}
\hline \multicolumn{1}{c|}{ Parameter } & Unit & Value \\
\hline Total groundwater reserves & $\mathrm{m}^{3}$ & n.a. \\
Total affected area (planning area) & $\mathrm{ha}$ & 54,026 \\
Specific groundwater reserve & $\mathrm{m}^{3} \mathrm{ha}^{-1}$ & $10,000-15,000$ \\
Annual groundwater extraction (based on water rights) & $\mathrm{m}^{3} \mathrm{y}^{-1}$ & $2,767,262$ \\
Irrigation cost of agricultural land**** & $\mathrm{HUF}\left(10 \mathrm{ha}^{-1} \mathrm{y}^{-1}\right.$ & 200,000 \\
Cost of unit extraction**** & $\mathrm{HUF} \mathrm{\textrm {m } ^ { - 3 }}$ & 300 \\
Worst scenario water price for irrigation water & $\mathrm{HUF} \mathrm{\textrm {m } ^ { - 3 }}$ & 40 \\
\hline
\end{tabular}

*The area of the Old Drava Programme. ${ }^{*}$ DDVIZIG 2015, Pécsi HYDROTERV 2015. ***KeménY, G. et al. 2018. ${ }^{* * * *}$ Cost calculations refer to national maximum costs of rotating sprinkler irrigation (at 2017 prices) using subsurface water only. Source: KeMÉNY, G. et al. 2018. n.a. = no data.

As a very rough estimate, in the short term, the value of the ES of groundwater recharge approximately equals the total extraction cost since the recharge is assumed to compensate for the loss of reserves through human extraction (see Figure 4). The starting date of observation of groundwater levels for most of the wells (1955) can be taken as reference and compared to groundwater levels in 2018. The drop of levels between these years indicated in the figure is due to two kinds of human action: - the construction of hydropower plants and their reservoirs upstream in Croatia, and - groundwater extraction.

If we calculate with actual groundwater recharge ranging from $0 \mathrm{~mm} \mathrm{y}^{-1}$ to $360 \mathrm{~mm} \mathrm{y}^{-1}$, the average being $241 \mathrm{~mm} \mathrm{y}^{-1}$ (SALEM, A. et al. 2020), the annual specific recharge is 0 to 36,000 $\mathrm{m}^{3} \mathrm{ha}^{-1}$, the average of which is $24,100 \mathrm{~m}^{3} \mathrm{ha}^{-1}$. Modelling also revealed the spatial distribution of recharge (Figure 7).

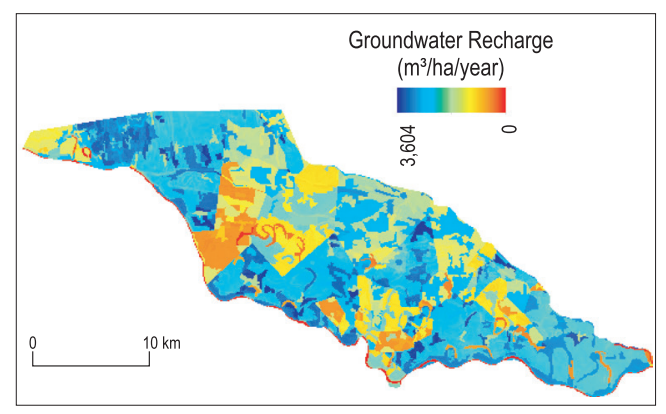

Fig. 7. Spatial distribution of groundwater recharge in the Hungarian Drava Plain (after SALEM, A. et al. 2020)
The actual price of irrigation water as of 2017 was HUF 8 m³ (Kemény, G. et al. 2018). Accordingly, the value of the ES 'groundwater recharge' can be estimated at HUF 192,800 ha $^{-1} \mathrm{y}^{-1}$ on the average and HUF 288,000 ha- $\mathrm{y}^{-1}$ at maximum. Calculating with the maximum predicted price of HUF $40 \mathrm{~m}^{-3}$, the ES is estimated at HUF 964,000 ha ${ }^{-1} \mathrm{y}^{-1}$ as an average and $1,440,000 \mathrm{ha}^{-1} \mathrm{y}^{-1}$ as a maximum. The latter values, however, seem to be unrealistic.

\section{Discussion}

There are several factors, processes and complications that may affect the above assumptions on the provision of ecosystem services and complicating their monetary evaluation: - With warming climate evaporation losses from the open water surfaces of shallow reservoirs and from soil surfaces would reduce surface water retention capacities and should also be considered.

- Natural processes, like the gradual entrenchment of the Drava River, also reduce reserves through "drawing down" the groundwater table. The groundwater table sank over 48 per cent of the area between 2008-2013 (DDVÍZIG 2015).

- Climate change results in aridification, increased water uptake by vegetation and dropping groundwater table. Summer half-year evapotranspiration is predicted to grow from the present-day maximum of $860 \mathrm{~mm}$ to $885-959 \mathrm{~mm}$ (Trinity Enviro 2018). 
- The groundwater budget shows yearly fluctuations (up to $2.5 \mathrm{~m}$ amplitude) with weather conditions.

- The value of floodwater retention and groundwater recharge services cannot be added up, because there is a significant overlap between them.

- Water prices play a decisive role in the calculations.

All these uncertainties also underline the need for a dynamic evaluation. However, at present it is not possible for Hungary because of data shortage. A monitoring network would allow for a dynamic approach to be realised.

How could a land evaluation scheme incorporate ecosystem services valuation? The aims of land evaluation as given in the original Framework (FAO 1976) remain wholly valid; where these refer to the identification of adverse effects and benefits of land uses, there is now greater emphasis on environmental consequences and on wider environmental benefits of ESs (FAO 2007). This way land evaluation could also be made more dynamic, adjusted to changing societal needs.

The incorporation of ESs assessment into the FAO land evaluation system is envisioned in the following way (Figure 8):

As a matter of course, it will be possible only if the methodology for the economic valuation of all ecosystem services is elaborated and validated.

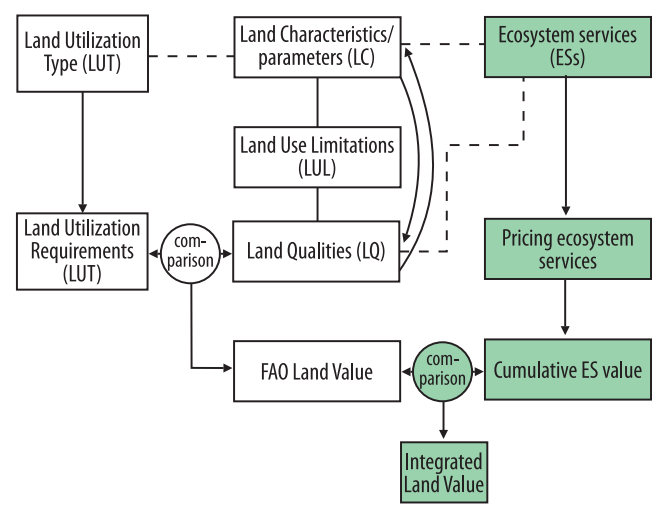

Fig. 8. A possibility of integrating ecosystem services valuation into conventional land evaluation (by Lóczy, D.)

\section{Conclusions}

The main goal of land evaluation schemes is to assess the efficiency of landscape functioning at present and under different environmental conditions of the future. The ongoing intensive research directed at ESs provides a new opportunity for the further development of land evaluation systems. In lack of appropriate information and limited knowledge on ecosystem structures and processes the assessment of ecosystem condition is often difficult. With global climate change water-related ESs (including water retention) increasingly come to the foreground. The presently used land evaluation systems are primarily based on static soil parameters which are easy to map and store in a GIS and could be extended to incorporate more dynamic variables that are in tune with the new societal demands. Dynamic and holistic land evaluation is needed, particularly for floodplains where water availability directly or indirectly defines the value of the land to a large extent.

The incorporation of ESs into the FAO evaluation framework seems to be an inevitable task for the future, such as advocated in FAO (2007). We show a clear and practical example of the incorporation of ESs into a LE framework for the Hungarian Drava Plain and the Kapos Valley. At present, however, a wide range of necessary conditions are missing. The price of water is the single decisive factor contributing to the value of water-related ESs.

The integrated assessment will only be possible if most of the important ESs are broken down to indicators by ecologists and expressed in monetary terms by environmental economists. The present study is only meant to be a first step in this direction.

Acknowledgements: Authors are grateful for financial support to the European Commission in the frame of the H2020 Diverfarming project (contract no 728003), to the GINOP-2.3.2.15-2016-00055 research fund and to the National Office for Research, Development and Innovation (NKFIH) within the Programme Excellence in Higher Education Institutions 2019 Topic II. 3. ("Innovation for sustainable life and environment"). 


\section{REFERENCES}

Acharya, G. 2000. Approaches to valuing the hidden hydrological services of wetland ecosystems. Ecological Economics 35. (1): 63-74. Doi: 10.1016/ S0921-8009(00)00168-3

Acharya, G., and BARBIER, E.B. 2000. Valuing groundwater recharge through agricultural production in the Hadejia-Jama'are Wetlands in Northern Nigeria. Agricultural Economics 22. 247-259. Doi: 10.1016/ S0169-5150(99)00054-7

Albert, C., Aronson, J., Fürst, C. and Opdam, P. 2014. Integrating ecosystem services in landscape planning: requirements, approaches, and impacts. Landscape Ecology 29. (8): 1277-1285. Doi: 10.1007/ s10980-014-0085-0

Albert, C., Gallera, C., Hermes, J., Neuendorf, F., von HaAren, C. and Lovett, A. 2016. Applying ecosystem services indicators in landscape planning and management: The ES-in-Planning framework. Ecological Indicators 61. (1): 100-113. Doi: 10.1016/j. ecolind.2015.03.029

Alexander, S., Aronson, J., Whaley, O. and Lamb, D. 2016. The relationship between ecological restoration and the ecosystem services concept. Ecology and Society 21. (1): 34-42. Doi: 10.5751/ES-08288-210134

Bakken, T.H., Lázár, A., Szomolányi, M., Németh, Á., TJomsland, T., Selvik, J.R., Borgvang, S.A. and FEHÉR, J. 2006. AQUAPOL-project: Model applications and comparison in the Kapos catchment, Hungary. Oslo, Norwegian Institute for Water Research. Available at https://niva.brage.unit.no/niva-xmlui/bitstream/ handle/11250/213168/5189_72dpi.pdf?sequence $=1$

BARTH, N.-C. and DölL, P. 2016. Assessing the ecosystem service flood protection of a riparian forest by applying a cascade approach. Ecosystem Services 21. (A): 39-52. Doi: 10.1016/j.ecoser.2016.07.012

Beek, K.J. and Bennema, J. 1972. Land Evaluation for Agricultural Land Use. Wageningen, NL, Department of Soil Science and Geology, Agricultural University.

Bergkamp, G. and Cross, K. 2006. Groundwater and Ecosystem Services: towards their sustainable use. Proceedings of International Symposium on Groundwater Sustainability (ISGWAS), Alicante, Spain, 24-27 January 2006. Madrid, Geological and Mining Institute of Spain, 177-193.

Bonfante, A., Monaco, E., Alfieri, S.M., De Lorenzi, F., Manna, P., Basile, A. and Bouma, J. 2015. Climate change effects on the suitability of an agricultural area to maize cultivation: Application of a new hybrid land evaluation system. Advances in Agronomy 133. 33-69. Doi: 10.1016/bs.agron.2015.05.001

Bonfante, A., Alfieri, S.M., Albrizio, R., Basile, A., De Mascellis, R., Gambuti, A., Giorio, P., Langella, G., Manna, P., Monaco, E., Moio, L. and Terribile, F. 2017. Evaluation of the effects of future climate change on grape quality through a physically based model application: a case study for the Aglianico grapevine in Campania region, Italy. Agricultural Systems 152. 100-109.

Bonfante, A., Monaco, E., Langella, Mercogliano, P., Bucchignani, E., Manna, P. and Terribile, F. 2018. A dynamic viticultural zoning to explore the resilience of terroir concept under climate change. Science of the Total Environment 624. 294-308. Doi: 10.1016/j.scitotenv.2017.12.035

Brower, R., LANGFord, I.H., BATEMAN, I.J. and TURNer, R.K. 1999. A meta-analysis of wetland contingent valuation studies. Regional Environmental Change 1. (1): 47-57. Doi: 10.1007/s101130050007

Brown, C., Seo, B. and Rounsevell, M. 2019. Societal breakdown as an emergent property of large-scale behavioural models of land use change. Earth System Dynamics 10. 809-845. Doi: 10.5194/esd-10-809-2019

Burkhard, B., Kroll, F., Müller, F. and Windhorst, W. 2009. Landscapes' capacities to provide ecosystem services - a concept for land-cover based assessments. Landscape Online 15. 1-22. Doi: 10.3097/ LO.200915

Chang, H. and Bonnette, M.R. 2016. Climate change and water-related ecosystem services: impacts of drought in California, USA. Ecosystem Health and Sustainability 2. (12): e01254. Doi: 10.1002/ehs2.1254

Costanza, R., D'Arge, R., de Groot, R.S., Farber, S., Grasso, M., Hannon, B., Limburg, K., Naeem, S., O’Neill, R.V., Paruelo, J., Raskin, R.G., Sutton, P. and VAN DEN BELT, M. 1997. The value of the world's ecosystem services and natural capital. Nature 387. (6630): 253-260.

Costanza, R. and Folke, C. 1997. Valuing ecosystem services with efficiency, fairness and sustainability as goals. In Nature's Services: Societal Dependence on Natural Ecosystems. Ed.: DAILY, G., Washington D.C., Island Press, 49-70.

CuI, L.J., PANG, B.L., LI, W., Ma, M.Y., Sun, B.D. and ZHANG, Y.Q. 2016. Evaluation of ecosystem services in the Zhalong wetland. Acta Ecologica Sinica 36. (3): 828-836. Doi: 10.5846/stxb201405161006

Damigos, D., Tentes, G., Balzarini, M., Furlanis, F. and Vianello, A. 2017. Revealing the economic value of managed aquifer recharge: Evidence from a contingent valuation study in Italy. Water Resources Research 53. 6597-6611. Doi: 10.1002/2016WR020281

Davidson, D.A. 1992. The Evaluation of Land Resources. $2^{\text {nd }}$ edition. Harlow, Essex, UK, Longman.

DDVÍZIG 2015. Dráva részvízgyüjtő. Vízgyüjtőgazdálkodási terv (Drava partial catchment. Water basin management plan). Pécs, DDVÍZIG.

Debaeke, P., Pellerin, S. and, Scopel, E. 2017. Climatesmart cropping systems for temperate and tropical agriculture: mitigation, adaptation and trade-offs. Cahiers Agricultures 26. (3): 34002. Doi: 10.1051/ cagri/2017028

Dér, F., Fábián, T., Hoffmann, R., Speiser, F. and Tо́тн, T. 2007. Gyepterületek földminősítése, földértékelése és földhasználati információja a D-e- 
Meter rendszerben (Land evaluation and land use information of grasslands in the D-e-meter scheme). In Földminősités, földértékelés és földhasználati információ. Ed.: GAÁL, Z., Veszprém, University of Veszprém, 59-64.

De Vries, W., Kros, J., Kroeze, C. and Seitzinger, S.P. 2013. Assessing planetary and regional nitrogen boundaries related to food security and adverse environmental impacts. Current Opinion in Environmental Sustainability 5. (3-4): 392-402. Doi: 10.1016/j.cosust.2013.07.004

Dezső, J., Czigány, Sz., Nagy, G., Pirkhoffer, E., SŁowik, M. and Lóczy, D. 2019. Monitoring soil moisture dynamics in multi-layered Fluvisols. Bulletin of Geography - Physical Geography Series 16. (1): 131-146. Doi: 10.2478/bgeo-2019-0009

Dezső, J., Lóczy, D., SAlem, A.M. and Nagy, G. 2019. Floodplain connectivity. In The Drava River: Environmental Problems and Solutions. Ed.: Lóczy, D., Cham, Switzerland, Springer Geography, 215-230. Doi: 10.1007/978-3-319-92816-6_14

Diadin, D., Vystavna, Y. and Vergeles, Y. 2018. Quantification of nitrate fluxes to groundwater and rivers from different land use types. Hungarian Geographical Bulletin 67. (4): 333-341. Doi: 10.15201/ hungeobull.67.4.3

Duarte, G.T., Santos, P.M., Cornelissen, T.G., Ribeiro, M.C. and PAglia, A.P. 2018. The effects of landscape patterns on ecosystem services: meta-analyses of landscape services. Landscape Ecology 33. (9): 1247-1257. Doi: 10.1007/s10980-018-0673-5

Eamus, D., Fu, B., Springer, A.E. and Stevens, L.E. 2016. Groundwater Dependent Ecosystems: Classification, Identification Techniques and Threats. In Integrated Groundwater Management. Eds.: JAKEMAN, A.J., Barreteau, O., Hunt, R.J., Rinaudo, J.D. and Ross, A., Cham, Switzerland, Springer, 313-346. Doi: https:// doi.org/10.1007/978-3-319-23576-9_13

EEA 2019. Climate change adaptation in the agriculture sector in Europe. EEA Report No 04/2019. Copenhagen, European Environment Agency. Doi: 10.2800/537176

Erhard, M., Banko, G., Abdul Malak, D. and SantosMARTín, F. 2017. Mapping ecosystem types and conditions. In Mapping Ecosystem Services. Eds.: BurKHARD, B. and Maes, J., Sofia, Pensoft Publishers, 75-80.

FALKenMARK, M. 2013. Growing water scarcity in agriculture: Future challenge to global water security. Philosophical Transactions of Royal Society, A. Mathematical Physical and Engineering Sciences 371. 20120410-20120410. Doi: 10.1098/rsta.2012.0410

FAO 1976. A framework for land evaluation. FAO Soils Bulletin 32. Rome, UN Food and Agriculture Organization. Available at http://www.fao.org/docrep/X5310E/x5310e00.htm

FAO 2007. Land evaluation - Towards a revised framework. Rome, UN Food and Agriculture Organization. Available at http://www.fao.org/nr/lman/docs/ lman_070601_en.pdf
FAO 2017. The future of food and agriculture: Trends and challenges. Rome, UN Food and Agriculture Organization. Available at http://www.fao.org/3/ai6881e.pdf

FArkas, J.Zs., Hoyk, E. and RakonczaI, J. 2017. Geographical analysis of climate vulnerability at a regional scale: the case of the Southern Great Plain in Hungary. Hungarian Geographical Bulletin 66. (2): 129-144. Doi: 10.15201/hungeobull.66.2.3

Fenér, Z.Zs. and Rakonczai, J. 2019. Analysing the sensitivity of Hungarian landscapes based on climate change induced shallow groundwater fluctuation. Hungarian Geographical Bulletin 68. (4): 355-372. Doi: 10.15201/hungeobull.68.4.3.

Fischer, B., Turner, R.K. and Morling, P. 2009. Defining and classifying ecosystem services for decision making. Ecological Economics 68. (3): 643-653. Doi: 10.1016/j.ecolecon.2008.09.014

Foster, T., Brozović, N. and Butler, A.P. 2017. Effects of initial aquifer conditions on economic benefits from groundwater conservation. Water Resources Research 53. 744-762. Doi: 10.1002/2016WR019365

Frutos Cachorro, J., Gobin, A. and Buysse, J. 2018. Farm-level adaptation to climate change: The case of the Loam region in Belgium. Agricultural Systems 165. 164-176. Doi: 10.1016/j.agsy.2018.06.007

Garofalo, P., Ventrella, D., Kersebaum, K.C., Gobin, A., Trnka, M., Giglio, L., Dubrovskŕ, M. and Castellinia, M. 2019. Water footprint of winter wheat under climate change: Trends and uncertainties associated to the ensemble of crop models. Science of the Total Environment 658. 1186-1208. Doi: 10.1016/j.scitotenv.2018.12.279

Gerten, D., Heinke, J., Hoff, H., Biemans, H., Fader, M. and WAHA, K. 2011. Global water availability and requirements for future food production. Journal of Hydrometeorology 12. 885-899. Doi: 10.1175/2011JHM1328.1

Gobin, A. 2010. Modelling climate impacts on crop yields in Belgium. Climate Research 44. (1): 55-68. Doi: 10.3354/cr00925

Gobin, A., Campling, P., Janssen, L., Desmet, N., van Delden, H., Hurkens, J., Lavelle, P. and BERMAN, S. 2011. Soil organic matter management across the EU - best practices, constraints and tradeoffs. Technical Report 2011-051. Final Report for the European Commission's DG Environment, September 2011. Brussels, European Commission. Doi: $10.2779 / 17252$

Gobin, A., Kersebaum, K.C., Eitzinger, J., Trnka, M., Hlavinka, P., Takáč, J., Kroes, J., Ventrella, D., Dalla Marta, A., Deelstra, J., Lalić, B., Nejedlik, P., Orlandini, S., Peltonen-Sainio, P., Rajala, A., SAue, T., ŞAylan, L., Stričevic, R., Vučetić, V. and Zoumides, C. 2017. Variability in the water footprint of arable crop production across European regions. Water 9. (2): 93-115. Doi: 10.3390/w9020093 
Griebler, C. and Avramov, M. 2015. Groundwater ecosystem services: a review. Freshwater Science 34. (1): 355-367. Doi: 10.1086/679903

Grizzetti, B., Lanzanova, D., Liquete, C., Reynaud, A. and CArdoso, A.C. 2016. Assessing water ecosystem services for water resource management. Environmental Science and Policy 61. 194-203. Doi: 10.1016/j.envsci.2016.04.008

Gscheidt, I. 2017. Záportározók építése a Baranyacsatorna vízgyüjtőjén (Building flood reservoirs on the catchment of the Baranya Canal). A Drávától a Balatonig 2017. (II): Pécs, DDVÍZIG, 5-6.

Haines-Young, R., Potschin, M. and Kienast, F. 2012. Indicators of ecosystem service potential at European scales: Mapping marginal changes and trade-offs. Ecological Indicators 21. 39-53. Doi: 10.1016/j.ecolind.2011.09.004

Haines-Young, R. and Potschin, M. 2018. Common International Classification of Ecosystem Services (CICES) V5.1. Guidance on the Application of the Revised Structure. Copenhagen, European Environmental Agency.

Hornung, L.K., Podschun, S.A. and Pusch, M. 2019. Linking ecosystem services and measures in river and floodplain management. Ecosystems and People 15. (1): 214-231. Doi: 10.1080/26395916.2019.1656287

JaKab, G., Bíró, T., Kovács, Z., Papp, Á., Sarawut, N., Szalai, Z., Madarász, B. and Szabó, Sz. 2019. Spatial analysis of changes and anomalies of intense rainfalls in Hungary. Hungarian Geographical Bulletin 68. (3): 241-253. Doi: 10.15201/hungeobull.68.3.3

Jankó, F., Bertalan, L., Hoschek, M., Komornoki, K., Németh, N. and Papp-Vancsó, J. 2018. Perception, understanding, and action: attitudes of climate change in the Hungarian population. Hungarian Geographical Bulletin 67. (2): 159-171. Doi: 10.15201/ hungeobull.67.2.4

Jódar-Abellán, A., Albaladejo-García, J.A. and PrAts-Rico, D. 2017. Artificial groundwater recharge: Review of the current knowledge of the technique. Revista de la Sociedad Geológica de España 30. (1): 85-96.

Kemény, G., Lámfalusi, I. and Molnár, A. (eds.) 2018. Az öntözhetöség természeti-gazdasági korlátainak hatása az öntözhetö területekre (Impact of the naturaleconomic limitations of irrigation potential on the irrigable areas). Budapest, Institute for Agroeconomic Research. Available at https://core.ac.uk/download/ pdf/158282715.pdf

Kertész, Á. and Ǩ̌̌čeK, J. 2019. Landscape degradation in the world and in Hungary. Hungarian Geographical Bulletin 68. (3): 201-221. Doi: 10.15201/ hungeobull.68.3.1

Kremen, C. 2005. Managing ecosystem services: what do we need to know about their ecology? Ecology Letters 8. (5): 468-479. Doi: 10.1111/j.1461-0248.2005.00751.x

Lóczy, D. 2000. A vízellátottság mint tájtulajdonság megítélése különböző földértékelési rendszerekben (Assessing water availability as a landscape property in various land evaluation systems). Földrajzi Értesítő / Hungarian Geographical Bulletin 49. (3-4): 215-230. (in Hungarian with English summary)

Lóczy, D. 2013. Land evaluation. In Hydromorphological and Geoecological Foundations of Floodplain Management: Case Study from Hungary. Ed.: Lóczy, D., Saarbrücken, Germany, Lambert Academic Publishing, 274-290.

Lovarelli, D., Bacenetti, J. and Fiala, M. 2016. Water Footprint of crop productions: A review. Science of The Total Environment 548-549. 236-251. Doi: 10.1016/j. scitotenv.2016.01.022

Lü, S.B., XU, S.G. and FenG, F. 2012. Floodwater utilisation values of wetland services - a case study in Northeastern China. National Hazards and Earth System Sciences 12. 341-349. Doi: 10.5194/nhess-12-341-2012

Maes, J., Teller, A., Erhard, M., Grizzetti, B., Barredo, J.I., Paracchini, M.L., Condé, S., Somma, F., Orgiazzi, A., Jones, A., Zulian, A., Vallecilo, S., Petersen, J.E., Marquardt, D., Kovacevic, V., Abdul Malak, D., Marin, A.I., Czúcz, B., Mauri, A., Loffler, P. Bastrup-Birk, A., Biala, K., Christiansen, T. and Werner, B. 2018. Mapping and Assessment of Ecosystems and their Services: Analytical Framework for Ecosystem Condition. Technical Report 2018-001. Luxembourg, Publications office of the European Union.

Major, P. 1994. A Duna-Tisza közi hátsági terület lefolyási viszonyainak, talajvíz-kitermelésének és a talajvízben történő szikkasztásnak hatása a talajvízszint változására (Impact of run-off, groundwater extraction and percolation to groundwater to the changes of groundwater table on the Danube-Tisza Interfluve). A Nagyalföld Alapítvány kötetei 3. Békéscsaba, MTA RKK ATI, 103-111.

Makovníková, J., PÁlKa, B., ŠiráŇ, M., Kizeková, M. and KaniansKa, R. 2019. The potential of regulating ecosystem service - filtering potential for inorganic pollutants - supplied by soils of Slovakia. Hungarian Geographical Bulletin 68. (2): 177-185. Doi: 10.15201/ hungeobull.68.2.5

Martin-Ortega, J., Ferrier, R.C., Gordon, I.J. and KHan, S. (eds.) 2015. Water Ecosystem Services: A Global Perspective. Cambridge, UK, Cambridge University Press.

McRae, S.G. and Burnham, C.P. 1981. Land Evaluation. Monographs of Soil Survey 7. Oxford, Clarendon Press.

MEA 2005. Millennium Ecosystem Assessment Synthesis Report. Washington, D.C., Island Press.

Monaco, E., Bonfante, A., Alfieri, S.M., Basile, A., Menenti, M. and de Lorenzi, F. 2014. Climate change, effective water use for irrigation and adaptability of maize: A case study in southern Italy. Biosystem Engineering 128. 82-99. Doi: 10.1016/j.biosystemseng.2014.09.001

Opperman, J.J., Luster, R., McKenney, B.A., Roberts, M. and Meadows, A.W. 2010. Ecologically functional floodplains: Connectivity, flow regime, and scale. 
Journal of the American Water Resources Association 46. (2): 211-226. Doi: 10.1111/j.1752-1688.2010.00426.x

Opperman, J.J., Moyle, P.B., Larsen, E.W., Florsheim, J.L. and Manfree, A.D. 2017. Floodplains: processes and management for ecosystems services. Oakland, CA, University of California Press. Available at https://meanderjpiric.files.wordpress.com/2018/01/ opperman-foodplains.pdf

Paruolo, P., Saisana, M. and Saltelli, A. 2013. Ratings and rankings: Voodoo or science? Journal of the Royal Statistical Society, Series A 176. (3): 609-634. Doi: 10.1111/i.1467-985X.2012.01059.x

Pascual, U. and Muradian, R. (eds.) 2010. The Economics of Ecosystems and biodiversity: Ecological and economic foundation. Cambridge-London, Earthscan Publications.

Pásztor, L., Szabó, J., Bakacsi, Zs. and Laborczi, A. 2013. Elaboration and applications of spatial soil information systems and digital soil mapping at Research Institute for Soil Science and Agricultural Chemistry of the Hungarian Academy of Sciences. Geocarto International 28. (1): 13-27. Doi: 10.1080/10106049.2012.685895

Pásztor, L., Laborczi, A., Bakacsi, Zs., Szabó, J. and ILlÉs, G. 2017. Compilation of a national soil-type map for Hungary by sequential classification methods. Geoderma 311. 93-108. Doi: 10.1016/j.geoderma.2017.04.018

Pécsi HYDROTERV 2015. Ős-Dráva Program. Aktualizált Területi Vízgazdálkodási Tanulmányterv (Old Drava Programme. Updated regional water management plan). Pécs, Pécsi HYDROTERV.

Potschin-Young, M., Czúcz, B., Liquete, C., Maes, J., Rusch, G.M. and Haines-Young, R. 2017. Intermediate ecosystem services: An empty concept? Ecosystem Services 27. 124-126. Doi: 10.1016/j.ecoser.2017.09.001

Rendon, P., Erhard, M., Maes, J. and Burkhard, B. 2019. Analysis of trends in mapping and assessment of ecosystem condition in Europe. Ecosystems and People 15. (1): 156-172. Doi: 10.1080/26395916.2019.1609581

Roberts, L.A. and Leitch, J.A. 1997. Economic Valuation of Some Wetland Outputs of Mud Lake, Minnesota-South Dakota. Agricultural Economics Report No. 381. Fargo, ND, North Dakota Agricultural Experiment Station - Department of Agricultural Economics, North Dakota State University.

Rockström, J., Steffen, W., Noone, K., Persson, Å., Chapin, F.S. III, Lambin, E.F., Lenton, T.M., Scheffer, M., Folke, C., Schellnhuber, H.J., Nykvist, B., DE Wit, C.A., Hughes, T., van der Leeuw, S., Rodhe, H., Sörlin, S., Snyder, P.K., Costanza, R., Svedin, U., Falkenmark, M., Karlberg, L., Corell, R.W., Fabry, V.J., Hansen, J., Walker, B., Liverman, D., Richardson, K., Crutzen, P. and Foley, J.A. 2009. A safe operating space for humanity. Nature 461. 472-475. Doi: 10.1038/461472a

Roux, B., VAN Der LaAN, M., VAhrmeijer, T., Bristow, K.L. and Annandale, J. 2017. Establishing and test- ing a catchment water footprint framework to inform sustainable irrigation water use for an aquifer under stress. Science of The Total Environment 599-600. 1119-1129. Doi: 10.1016/j.scitotenv.2017.04.170

SaAb, M.T.A., Sellami, M.H., Giorio, P., Basile, A., Bonfante, A., Rouphael, Y., Fahed, S., JomaA, I., Stephan, C., Kabalan, R., Massaad, R., Todorovic, M. and Albrizio, R. 2019. Assessing the potential of cereal production systems to adapt to contrasting weather conditions in the Mediterranean region. Agronomy 9. (7): 393-414. Doi: 10.3390/agronomy9070393

SAlem, A., Dezső, J. and El-Rawy, M. 2019. Assessment of groundwater recharge, evaporation, and run-off in the Drava Basin in Hungary with the WetSpass Model. Hydrology 6. 23-34. Doi: 10.3390/hydrology6010023

Salem, A., Dezső, J., El-Rawy, M. and Lóczy, D. 2020. Hydrological modelling to assess the efficiency of groundwater replenishment through natural reservoirs in the Hungarian Drava River floodplain. Water 12. 250-270. Doi: 10.3390/w12010250

Sanon, S., Hein, T., Douwen, W. and Winkler, P. 2012. Quantifying ecosystem service trade-offs: The case of an urban floodplain in Vienna, Austria. Journal of Environmental Management 111. 159-172. Doi: 10.1016/j.jenvman.2012.06.008

Scanlon, B.R., Healy, R.W. and Cook, P.G. 2002. Choosing appropriate techniques for quantifying groundwater recharge. Hydrogeology Journal 10. 18-39. Doi: 10.1007/s10040-001-0176-2

Schils, R., Olesen, J., Kersebaum, K., Rijk, B., Oberforster, M., Kalyada, V., Khitrykau, M., Gobin, A., Kirchev, H., Manolova, V., Manolov, I., Trnka, M., Hlavinka, P., Paluoso, T., Peltonen-Sainio, P., Jauhiainen, L., Lorgeou, J., Marrou, H., Danalatos, N., Archontoulis, S., Fodor, N., Spink, J., Roggero, P., Bassu, S., Pulina, A., Seehusen, T., Uhlen, A., ŻyŁowsKa, K., Nieróbca, A., Kozyra, J., Silva, J., Maçãs, B., Coutinho, J., Ion, V., Takáč, J., Mínguez, M., Eckersten, H., Levy, L., Herrera, J., Hiltbrunner, J., Kryvobok, O., Kryvoshein, O., Sylvester-Bradley, R., Kindred, D., Topp, C., BoogaArd, H., de Groot, H., Lesschen, J., van Bussel, L., Wolf, J., Zijlstra, M., van Loon, M. and van ItTersum, M. 2018. Cereal yield gaps across Europe. European Journal of Agronomy 101. 109-120. Doi: 10.1016/j.eja.2018.09.003

Schindler, S., Kropik, M., Euller, K., Bunting, S.W., Schulz-Zunkel, C., Hermann, A., Hainz-Renetzeder, C., Kanka, R., Mauerhofer, V., Gasso, V., Krug, A., LauwaArs, S.G., Zulka, K.P., Henle, K., Hoffmann, M., Biró, M., Essl, F., JaQuier, S., Balázs, L., Borics, G., Hudin, S., Damm, C., Pusch, M., van der Sluis, T., Sebesvári, Z. and WrbKa, T. 2013. Floodplain management in temperate regions: Is multifunctionality enhancing biodiversity? Environmental Evidence 2. (10): 1-11. Doi: 10.1186/2047-2382-2-10 
Schindler, S., Sebesvári, Z., Damm, C., Euller, K., Mauerhofer, V., Hermann, A., Biró, M., Essl, F., Kanka, R., Lauwaars, S.G., Schulz-Zunkel, C., van der Sluis, T., Kropik, M., Gasso, V., Krug, A., Pusch, M., Zulka, K.P., Lazowski, W., Hainz-Renetzeder, C., Henle, K. and WrbKa, T. 2014. Multifunctionality of floodplain landscapes: relating management options to ecosystem services. Landscape Ecology 29. (2): 229-244. Doi: 10.1007/s10980-014-9989-y

Simpson, R.D. 2017. The simple but not-too-simple valuation of ecosystem services: basic principles and an illustrative example. Journal of Environmental Economics and Policy 6. 96-106. Doi: 10.1080/21606544.2016.1184594

Smit, B., Brklacich, M.J., Dumanski, J., Macdonald, K.B. and Miller, M.H. 1984. Integral land evaluation and its application to policy. Canadian Journal of Soil Science 64. 467-479.

Supit, I., van Diepen, C.A., de Wit A.J., Kabat, W.P., BARUth, B. and Ludwig, F. 2010. Recent changes in the climatic yield potential of various crops in Europe. Agricultural Systems 103. (9): 683-694. Doi: 10.1016/j. agsy.2010.08.009

Szabó, Sz., Szopos, N.M., Bertalan-Balázs, B., László, E., Milošević, D.D., Conoscenti, C. and LÁzár, I. 2019. Geospatial analysis of drought tendencies in the Carpathians as reflected in a 50-year time series. Hungarian Geographical Bulletin 68. (3): 269-282. Doi: 10.15201/hungeobull.68.3.5

Szappanos, F., Széles, I. and ViráG, M. 1976. A Kapos vízrendezése tárolással (Regulation of the Kapos River by storage). Vízügyi Közlemények 58. (4): 531-544.

Talbot, C.J., Bennett, E.M., Cassell, K., Hanes, D.M., Minor, E.C., Paerl, H., Raymond, P.A., Vargas, R., Vidon, P.G., Wollheim, W. and Xenopoulos, M.A. 2018. The impact of flooding on aquatic ecosystem services. Biogeochemistry 141. 439-461. Doi: 10.1007/ s10533-018-0449-7

Tanács, E., Belényesi, M., Lehoczki, R., Pataki, R., Petrik, O., Standovár, T., Pásztor, L., Laborczi, A., Szatmári, G., Molnár, Zs., Bede-Fazekas, Á., Kisné Fodor, L., VArga, I., Zsembery, Z. and Maucha, G. 2019. Országos, nagyfelbontású ökoszisztémaalaptérkép: módszertan, validáció és felhasználási lehetőségek (National large-scale ecosystem base map: validation and utilization opportunities). Természetvédelmi Közlemények 25.34-58. Doi: 10.17779/ tvk-jnatconserv.2019.25.34

TerraexpertKft. 2018. Medrekszivárgásiveszteségénekmeghatározása az Ös-Dráva (KEHOP-1.3.0-15-2016-00014) projektben helyszini és laboratóriumi vizsgálatok, valamint 2D modellezés alapján (Seepage losses of channels in the Old Drava Programme [KEHOP-1.3.0-15-2016-00014] based on field and laboratory studies and 2D modelling). Budapest, Terraexpert Kft.

Thurston, H.W., Heberling, M.T. and Schrecongost, A. (eds.) 2009. Environmental Economics for Watershed Restoration. Boca Raton, FL, CRC Press.
Tо́тн, G. 2009. Land evaluation with the D-e-Meter system. Agrokémia és Talajtan 58. (2): 227-242. Doi: 10.1556/Agrokem.58.2009.2.5

Tóth, G., Tóth, B., Pásztor, L., Fodor, N., Hermann, T., Kocsis, M., Máté, F., Szatmári, G., Laborczi, A., TAKÁcs, K. and Sieglerné Matus, J. 2018. Land quality. In National Atlas of Hungary. Ed.-in-chief: Kocsis, K., Budapest, Geographical Research Institute, Centre for Astronomy and Earth Sciences, Hungarian Academy of Sciences.

Trinity Enviro 2018. Vízvisszatartás és tájhasználatváltás az Ós-Dráva projektben (Water retention and land use change in the Old Drava Programme). Budapest, Trinity Enviro.

Valett, H.M., Baker, M.A., Morrice, J.A., Crawford, C.S., Molles, M.C., Dahm, C.N., Moyer, D.L., Thibault, J.R. and Ellis, L. M. 2005. Biogeochemical and metabolic responses to the flood pulse in a semiarid floodplain. Ecology 86. (1): 220-234. Doi: 10.1890/03-4091

Van Grinsven, H.J.M., Bouwman, L., Cassman, K.G., van Es, H.M., McCrackin, M.L. and Beusen, A.H.W. 2015. Losses of Ammonia and Nitrate from Agriculture and Their Effect on Nitrogen Recovery in the European Union and the United States between 1900 and 2050. Journal of Environmental Quality 44. 356-367. Doi:10.2134/jeq2014.03.0102

Vandecasteele, I., Marí i Rivero, I. Baranzelli, C., Becker, W., Dreoni, I., Lavalle, C. and Batelaan, O. 2018. The Water Retention Index: Using land use planning to manage water resources in Europe. Sustainable Development 26. 122-131. Doi: 10.1002/sd.1723

Walker, D., Parkin, G., Schmitter, P., Gowing, J., Tilahun, S.A., Haile, A.T. and Yimam, A.Y. 2018 Insights from a multi-method recharge estimation comparison study. Groundwater 57. (2): 245-258. Doi: 10.1111/gwat.12801

Wu, J. 2013. Landscape sustainability science: ecosystem services and human well-being in changing landscapes. Landscape Ecology 28. (6): 999-1023. Doi: 10.1007/s10980-013-9894-9

Xu, H. and Wu, M. 2017. Water Availability Indices A Literature Review. Report ANL/ESD-17/5. Argonne, ILL, Argonne National Laboratory, U.S. Department of Energy. Available at https://water.es.anl.gov/ documents/Technical_Report_Literature_Review_ of_Water_Availability_Indices_030317.ems_vs.pdf

Zulian, G., Paracchini, M.L., Maes, J. and Liquete, C. 2013. ESTIMAP: Ecosystem services mapping at European scale. Report EUR 26474 EN. Ispra, VA, Italy. European Commission, Joint Research Centre, Institute for Environment and Sustainability. Doi $10.2788 / 64369$ 
